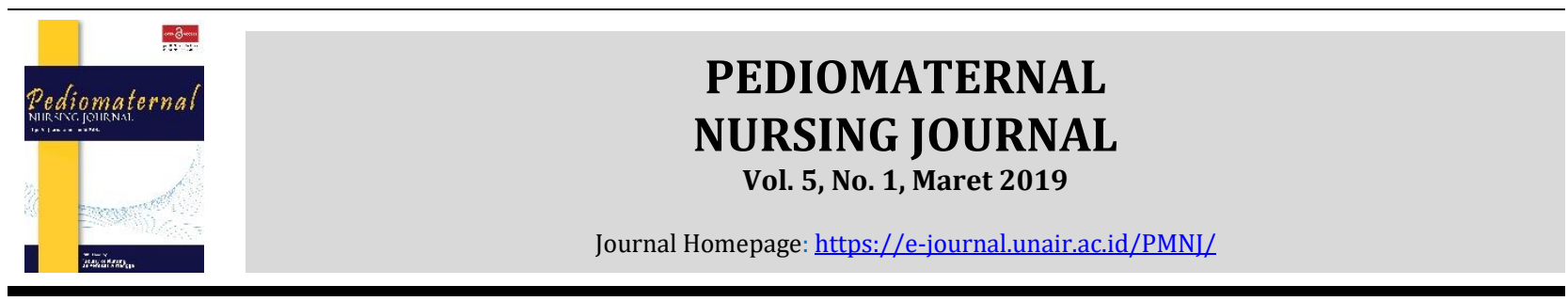

Original Research

\title{
Pendekatan Teori Health Belief Model terhadap Perilaku Ibu dalam Pemenuhan Kebutuhan Nutrisi Anak Usia Toddler
}

\author{
(The Health Belief Model Theory Approach to Mother Behavior in Fulfilling Nutrition Needs for \\ Toddler)
}

\section{Rambu Eri Hupunau, Retnayu Pradanie, dan Tiyas Kusumaningrum}

Fakultas Keperawatan, Universitas Airlangga, Surabaya, Jawa Timur, Indonesia

\author{
ARTICLE HISTORY \\ Received: March 17, 2019 \\ Accepted: March 26, 2019
}

\section{KEYWORDS}

toddler; mother's behavior health belief model theory

\section{CORRESPONDING AUTHOR}

Rambu Eri Hupunau rambu.eri.hupunau2017@fkp.unair.ac.id Fakultas Keperawatan, Universitas Airlangga, Surabaya, Jawa Timur, Indonesia

\begin{abstract}
Introduction: Toddler is an important period in child growth that will determine the development of children in the future. If nutritional needs are not met properly during infancy, it will lead to malnutrition of children who are susceptible to infection, muscle management, swelling of the liver, and organ abnormalities and functions (due to atrophy). The purpose of this study was to explain the factors that influence the mother in providing nutritional needs of toddlers with the health belief model approach.

Methods: This study design was descriptive with cross sectional approach. Total sampel in this study was 174 mothers respondents who has child with age 1-3 years. Independent variabel in this study were perceived suceptibility, perceived severity, perceived benefit, perceived barrier, cues to action and self eficacy. Dependent variabel study was Mother's behavior in providing nutrition. Sampel were taken by Cluster random sampling. The data were collected by questionnaire. Data were analyzed with spearmen rho test with significance level $\alpha<0.05$.

Results: The result showed that perceived suceptibility $(\mathrm{p}=0.382)$, perceived severity $(p=0.116)$, perceived benefit $(p=0.182)$, cues to action $(p=0.075)$ and self eficacy $(\mathrm{p}=0.132)$ theres was no relationship between mother's behavior and perceived barrier $(\mathrm{p}=0.033)$ have relationship with mother's behavior.

Conclusion: Health workers in Puskesmas should do intensive health education about good nutrition and the consequences that can occur if lack of nutrition in toddler children. Then for mothers as respondents to empower local food available to be a source of nutritional substitutes and use the home page to become a family garden by planting various types of vegetables.
\end{abstract}

Cite this as:

Hupunau, R. E., Pradanie, R., \& Kusumaningrum, T. (2019). Pendekatan Teori Health Belief Model terhadap Perilaku Ibu dalam Pemenuhan Kebutuhan Nutrisi Anak Usia Toddler. Pediomaternal Nurs. J., 5(1), 1-8.

\section{PENDAHULUAN}

Indonesia sebagai salah satu negara yang sedang berkembang masih menghadapi masalah kekurangan gizi yang cukup besar. Data (1) didapatkan bahwa 1,5 juta balita khususnya usia toddler meninggal karena pemberian makanan yang tidak tepat dan $90 \%$ diantaranya terjadi dinegara berkembang. Masalah gizi yang sampai saat ini masih menjadi masalah di tingkat nasional adalah gizi kurang pada toddler, anemia, Gangguan Akibat Kekurangan Yodium (GAKY) dan kurang vitamin A.

Kekurang gizi pada tingkat ringan dan atau sedang masih seperti anak-anak lain, beraktivitas, bermain dan sebagainya, tetapi bila diamati dengan seksama badannya mulai kurus dan staminanya mulai menurun. Pada fase lanjut (gizi buruk) akan rentan terhadap infeksi, terjadi pengurusan otot, pembengkakan hati, dan berbagai gangguan yang lain seperti misalnya peradangan kulit, infeksi, kelainan 
organ dan fungsinya (akibat atrophy/pengecilan organ tersebut) (2)

Hasil wawancara studi data awal dengan petugas di Puskesmas Kawangu mengatakan bahwa masih banyak terdapat kasus karena kekurangan gizi dan perilaku Ibu di wilayah kerja Puskesmas Kawangu secara umum belum sesuai harapan. Hasil wawancara 10 orang Ibu dengan anak usia toddler 5 orang mengatakan anaknya sulit untuk makan dan hanya suka mengkonsumsi ikan tidak suka makan sayur, 2 orang Ibu mengatakan anaknya suka jajan makanan ringan (ciki), dan 3 orang Ibu mengatakan tidak ada kesulitan makan pada anaknya kecuali kalau anaknya sakit atau tumbuh gigi.

Data Dinkes Kabupaten Sumba Timur tahun 2017 jumlah total balita di Kabupaten Sumba Timur adalah 24.650. Kejadian gizi kurang 460 kasus atau $1.86 \%$, dan kejadian gizi buruk 174 kasus atau $0.7 \%$ (3). Puskesmas Kawangu adalah salah satu Puskesmas yang letaknya dekat dengan kota Waingapu dan diantara 3 Puskesmas yang letaknya dekat dengan kota Waingapu, Puskesmas Kawangu mempunyai angka kejadian gizi buruk dan kurang yang paling tinggi. Survey awal didapatkan data untuk Tahun 2017 gizi buruk sebanyak 12 kasus atau $0.9 \%$ dari total populasi, gizi kurang sebanyak 14 kasus atau $1.05 \%$, partisipasi masyarakat ke posyandu $89.8 \%$, imunisasi dasar lengkap $103.03 \%$. Tahun 2018 sampai pada bulan Agustus gizi buruk 10 kasus atau $0.51 \%$ ( 7 anak usia toddler) dan gizi kurang 27 kasus atau $1.38 \%$ (20 anak usia toddler) (4).

Status gizi balita sangat dipengaruhi oleh asupan nutrisi yang didapat dari makanan sehari-hari. Peran orang tua terutama Ibu sangat penting untuk menjaga balita terhindar dari kekurangan gizi. Menurut teori Health Belief Model perilaku kesehatan dipengaruhi oleh perceived susceptibility (kerentanan yang dirasakan/diketahui), perceived severity (bahaya/kesakitan yang dirasakan), perceived benefit (manfaat yang dirasakan dari tindakan yang diambil), perceived barrier (hambatan yang dirasakan akan tindakan yang diambil), cues to action (isyarat untuk melakukan tindakan) dan self efficacy atau keyakinan untuk melakukan perilaku kesehatan.

\section{METODE}

\subsection{Desain}

Penelitian ini menggunakan rancangan penelitian Analitik cross sectional.

\subsection{Populasi, sampel, dan sampling}

Populasi dalam penelitian ini adalah semua Ibu yang mempunyai anak usia toddler di Puskesmas Kawangu (Desa Kambatatana, desa Palakahembi dan kelurahan Kawangu). Sampel penelitian ini sebanyak 174 orang dan teknik pengambilan sampel pada penelitian ini menggunakan Cluster sampling.

\subsection{Variabel}

Variabel independent dalam penelitian ini adalah perceived susceptibility (kerentanan yang dirasakan/ diketahui), perceived severity (bahaya/ kesakitan yang dirasakan), perceived benefit of action (manfaat yang dirasakan dari tindakan yang diambil), perceived barrier to action (hambatan yang dirasakan akan tindakan yang diambil), cues to action (isyarat untuk melakukan tindakan) dan self efficacy. Variabel dependent pada penelitian ini adalah perilaku Ibu dalam pemenuhan kebutuhan nutrisi pada anak usia toddler.

\subsection{Instrumen}

Kuesioner data demografi merupakan kuesioner yang dilampirkan untuk mengetahui informasi secara umum pada responden. Ada 5 pertanyaan mengenai responden yang terdiri atas umur responden, pendidikan responden, ekonomi/pendapatan, pekerjaan responden dan jumlah anak. Kemudian juga pertanyaan tambahan berupa usia anak, Jenis kelamin anak, jumlah anak, BB anak, TB anak dan status gizi anak (untuk status gizi disi oleh peneliti dan data diambil data dari Puskemas).

Kuesiner perceived Susceptibility diukur dengan skala likert, dengan pilihan jawaban yang terdiri dari Pernyataan terdiri sangat tidak setuju (STS ), sangat setuju (ST), setuju (S) dan sangat setuju (SS). Pernyataan terdiri dari 6 item. Skor untuk jawaban Favorable $(1,2,3,4) \quad \mathrm{STS}=1, \mathrm{TS}=2, \mathrm{~S}=3, \mathrm{SS}=4$ sedangkan skor untuk jawaban Unfavorable $(5,6)$ $\mathrm{STS}=4, \mathrm{TS}=3, \mathrm{~S}=2, \mathrm{SS}=1$. Kemudian setelah prosentase diketahui hasilnya diinterpretasikan dengan kategori tinggi $=76 \%-100 \%$, sedang $=60 \%-75 \%$ dan rendah $=$ $<60 \%$. Nilai alpha cronbach $\alpha=0,761 \mathrm{~N}=6$

Kuesiner perceived severity diukur dengan skala likert, dengan pilihan jawaban yang terdiri dari Pernyataan terdiri sangat tidak setuju (STS ), sangat setuju (ST), setuju (S) dan sangat setuju (SS). Pernyataan terdiri dari 7 item. Skor untuk jawaban Favorable $(1,2,3,4)$ STS $=1, \mathrm{TS}=2, \mathrm{~S}=3, \quad \mathrm{SS}=4$ sedangkan skor untuk jawaban Unfavorable $(5,6,7)$ $\mathrm{STS}=4, \mathrm{TS}=3, \mathrm{~S}=2, \mathrm{SS}=1$. Kemudian setelah prosentase diketahui hasilnya diinterpretasikan dengan kategori tinggi $=76 \%-100 \%$, sedang $=60 \%-75 \%$ dan rendah $=$ $<60 \%$. Nilai alpha cronbach $\alpha=0,883, N=7$

Kuesioner perceived benefit diukur dengan skala likert, dengan pilihan jawaban yang terdiri dari Pernyataan terdiri sangat tidak setuju (STS ), sangat setuju (ST), setuju (S) dan sangat setuju (SS). Pernyataan terdiri dari 6 item. Skor untuk jawaban Favorable $(1,2,3) \mathrm{STS}=1, \mathrm{TS}=2, \mathrm{~S}=3, \mathrm{SS}=4$ sedangkan skor untuk jawaban Unfavorable $(4,5,6) \mathrm{STS}=4, \mathrm{TS}=3$, $\mathrm{S}=2, \mathrm{SS}=1$. Kemudian setelah prosentase diketahui hasilnya diinterpretasikan dengan kategori tinggi = $76 \%-100 \%$, sedang $=60 \%-75 \%$ dan rendah $=<60 \%$. Nilai alpha cronbach $\alpha=0,779, N=6$

Kuesioner perceived barrier diukur dengan skala likert, dengan pilihan jawaban yang terdiri dari Pernyataan terdiri sangat tidak setuju (STS ), sangat setuju (ST), setuju (S) dan sangat setuju (SS). Pernyataan terdiri dari 5 item. Skor untuk jawaban Favorable $(1,2,3,4,5)$ STS $=1, \mathrm{TS}=2, \mathrm{~S}=3, \mathrm{SS}=4$. Kemudian setelah prosentase diketahui hasilnya diinterpretasikan dengan kategori Rendah $=76 \%$ - 
$100 \%$, sedang $=60 \%-75 \%$ dan Tinggi $=<60 \%$. Nilai alpha cronbach $\alpha=0,779, N=5$

Kuesioner perceived cues to action diukur dengan skala likert, dengan pilihan jawaban yang terdiri dari Pernyataan terdiri sangat tidak setuju (STS ), sangat setuju (ST), setuju (S) dan sangat setuju (SS). Pernyataan terdiri dari 6 item. Skor untuk jawaban Favorable $(1,2,3,4)$ STS $=1, \mathrm{TS}=2, \mathrm{~S}=3, \mathrm{SS}=4$ sedangkan skor untuk jawaban Unfavorable $(5,6)$ $\mathrm{STS}=4, \mathrm{TS}=3, \mathrm{~S}=2$, SS=1. Kemudian setelah prosentase diketahui hasilnya diinterpretasikan dengan kategori tinggi $=76 \%-100 \%$, sedang $=60 \%-75 \%$ dan rendah $=$ $<60 \%$. Nilai alpha cronbach $\alpha=0,856, N=6$.

\subsection{Prosedur}

Identifikasi responden dengan langkah awal memberikan penjelasan penelitian dan inform concent untuk ditandatangani oleh responden. Memberikan kuesioner kepada responden untuk mengetahui faktor-faktor yang mempengaruhi perilaku Ibu dalam pemenuhan kebutuhan nutrisi pada anaknya. Mendampingi responden saat pengisian kuesioner untuk memastikan tidak ada pertanyaan yang tidak dipahami oleh responden. Setelah kuesioner diisi oleh responden, maka selanjutnya dilakukan pengecekan terhadap pengisian kuesioner untuk memastikan bahwa kuesioner telah diisi lengkap oleh responden. Setelah data terkumpul maka proses selanjutnya adalah proses pengolahan data untuk dianalisis.

\subsection{Analisis}

Penelitian ini dilakukan analisa dengan IBM SPSS statistik 21 dengan uji statistik korelasi Spearmen's $R h o \propto \leq 0.05$.

\subsection{Ethical Clearance}

Penelitian ini telah mendapatkan sertifikat etik dari KEPK Universitas Airlangga Fakultas Keperawatan dengan no 119-KEPK

\section{Hasil}

Karakteristik responden dari segi umur, semua responden berada pada usia produktif yaitu umur 2150 tahun dengan presentase terbanyak pada usia 2529 tahun (46\%) dan usia 30-34 tahun (46\%). Dilihat dari pendapatan sebagian besar responden atau 116 orang $(66.7 \%)$ memiliki pendapatan rendah (dibawah UMR), dari segi pendidikan hampir sebagian pendidikan SD/sederajat (42\%)dan dilihat dari pekerjaan responden sebagian besar adalah petani sebanyak 92 orang (52.9\%) [Tabel 1].

Karakteristik anak berdasarkan umur menunjukkan lebih sebagian besar anak dari responden berumur 1-2 tahun sebanyak 114 orang (65.6\%), Jenis kelamin anak sebagian besar laki-laki sebanyak 88 orang (50.6\%), untuk jumlah anak tidak ada perbedaan yang signifikan untuk status gizi semua nya sebanyak 174 orang anak (100\%) gizi baik [Tabel 2].
Hasil analisa statistik dengan menggunakan uji korelasi spearman rho dengan tingkat kemaknaan $<0.05$ didapati hasil yaitu pada persepsi kerentanan nilai $\mathrm{p}=0.382$ dan korelasi $\mathrm{r}=0.067$. Nilai $\mathrm{p}$ lebih besar dari 0.05 yang berarti $\mathrm{H} 1$ ditolak dan H0 diterima, hasil analisa tersebut menunjukkan tidak ada hubungan antara persepsi kerentanan dan perilaku Ibu dalam pemenuhan kebutuhan nutrisi pada anak usia toddler. Pada persepsi keseriusan nilai $\mathrm{p}=0.116$ dan $r=0.127$. Nilai $p$ lebih besar dari 0.05 yang berarti $\mathrm{H} 1$ ditolak dan H0 diterima, hasil analisa tersebut menunjukkan tidak ada hubungan antara persepsi keseriusan dan perilaku Ibu dalam pemenuhan kebutuhan nutrisi pada anak usia toddler. Pada persepsi manfaat nilai $\mathrm{p}=0.182$ dan $\mathrm{r}=0.102$. Nilai p lebih besar dari 0.05 yang berarti H1 ditolak dan H0 diterima, hasil analisa tersebut menunjukkan tidak ada hubungan antara persepsi manfaat dan perilaku Ibu dalam pemenuhan kebutuhan nutrisi pada anak usia toddler. Untuk persepsi hambatan ditemukan nilai $\mathrm{p}=0.033$ dan korelasi $\mathrm{r}=0.162$. Nilai p lebih kecil dari 0.05 yang berarti $\mathrm{H} 1$ diterima dan $\mathrm{HO}$ ditolak, hasil analisa tersebut menunjukkan ada hubungan yang sangat lemah antara persepsi hambatan dan perilaku Ibu dalam pemenuhan kebutuhan nutrisi pada anak usia toddler. Untuk cues to action nilai $\mathrm{p}=0.075$ dan korelasi $\mathrm{r}=0.135$. Nilai $\mathrm{p}$ lebih besar dari 0.05 yang berarti $\mathrm{H} 1$ ditolak dan $\mathrm{H} 0$ diterima, hasil analisa tersebut menunjukkan tidak ada hubungan antara cues to action dengan perilaku Ibu dalam pemenuhan kebutuhan nutrisi pada anak usia toddler.Sedangkan untuk self eficacy, nilai $\mathrm{p}=$ 0.132 dan korelasi $r=0.115$. Nilai $p$ lebih besar dari 0.05 yang berarti $\mathrm{H} 1$ ditolak dan $\mathrm{H} 0$ diterima, hasil analisa tersebut menunjukkan tidak ada hubungan antara self eficacy dengan perilaku Ibu dalam pemenuhan kebutuhan nutrisi pada anak usia toddler [Tabel 3].

\section{PEMBAHASAN}

4.1 Hubungan antara persepsi kerentanan dengan perilaku Ibu dalam pemenuhan kebutuhan nutrisi bagi usia toddler

Berdasarkan hasil penelitian sebanyak 21.8\% mememilki persepsi kerentanan yang rendah. Dari 21.8\%, 12\% memiliki perilaku pemenuhan nutrisi yang baik dan $9.8 \%$ mempunyai perilaku pemenuhan nutrisi yang tidak baik. Masih adanya responden yang memiliki persepsi kerentanan yang rendah ditunjukan dengan nilai jawaban responden yang rendah pada kuesioner penelitian (pernyataan 1,2,3) parameter kesehatan. Dari data dapat dilihat bahwa sekalipun responden memiliki persepsi kerentanan yang rendah tetapi masih lebih banyak yang mempunyai perilaku pemenuhan kebutuhan nutrisi yang baik daripada responden yang mempunyai perilaku tidak baik. Kemudian sebanyak 28.2\% memiliki persepsi kerentanan yang tinggi, 16.7\% mempunyai perilaku yang baik dalam pemenuhan kebutuhan nutrisi anaknya dan $11.5 \%$ tidak 
Tabel 1. Karakteristik responden di wilayah kerja Puskesmas Kawangu, Desember 2018

\begin{tabular}{|c|c|c|c|}
\hline & Kategori & Frekuensi & Presentase (\%) \\
\hline \multirow[t]{6}{*}{ Umur } & 20-24 tahun & 33 & 19 \\
\hline & 25-29 tahun & 46 & 26,4 \\
\hline & 30-34 tahun & 46 & 26,4 \\
\hline & 35-39 tahun & 33 & 19 \\
\hline & 40-44 tahun & 14 & 8,0 \\
\hline & 45-49 tahun & 2 & 1,1 \\
\hline Total & & 174 & 100 \\
\hline \multirow[t]{4}{*}{ Pendidikan } & $\mathrm{SD} /$ sederajat & 73 & 42 \\
\hline & SMP/sederajat & 21 & 12,1 \\
\hline & SMA/sederajat & 60 & 34,5 \\
\hline & $\mathrm{PT}$ & 20 & 11,5 \\
\hline Total & & 174 & 100 \\
\hline \multirow[t]{3}{*}{ Pendapatan } & $<1.600 .000$ & 116 & 66,7 \\
\hline & $>1.600 .000$ & 58 & 33,3 \\
\hline & Total & 174 & 100 \\
\hline \multirow[t]{5}{*}{ Pekerjaan } & Petani & 92 & 52,9 \\
\hline & Wiraswasta & 2 & 1,1 \\
\hline & Pengrajin & 27 & 15,5 \\
\hline & IRT & 40 & 23,0 \\
\hline & PNS/Karyawati/Honorer & 13 & 7,5 \\
\hline Total & & 174 & 100 \\
\hline \multirow[t]{4}{*}{ Jumlah anak } & 1 & 50 & 28,7 \\
\hline & 2 & 46 & 26,4 \\
\hline & 3 & 35 & 20,1 \\
\hline & Jml anak $>3$ & 43 & 24,7 \\
\hline Total & & 174 & 100 \\
\hline & Kategori & Frekuensi & Presentase (\%) \\
\hline \multirow[t]{2}{*}{ Umur } & 1-2 Tahun & 114 & 65,5 \\
\hline & $>2$ tahun & 60 & 34,5 \\
\hline Total & & 174 & 100 \\
\hline \multirow[t]{2}{*}{ Jenis kelamin } & Laki-laki & 88 & 50,6 \\
\hline & Perempuan & 86 & 49,4 \\
\hline Total & & 174 & 100 \\
\hline \multirow[t]{4}{*}{ Anak ke } & 1 & 55 & 31,6 \\
\hline & 2 & 45 & 25,9 \\
\hline & 3 & 35 & 20,1 \\
\hline & Anak ke >3 & 39 & 22,4 \\
\hline Total & & 174 & 100 \\
\hline Status gizi & Gizi baik & 174 & 100 \\
\hline Total & & 174 & 100 \\
\hline
\end{tabular}

mempunyai perilaku yang baik dalam pemenuhan kebutuhan nutrisi.

Data menunjukkan bahwa responden dengan persepsi kerentanan yang tinggi cenderung memiliki perilaku yang baik dalam pemenuhan kebutuhan nutrisi untuk anaknya. Untuk responden dengan persepsi kerentanan sedang sebanyak 50\% dimana responden yang memiliki perilaku baik sebanyak $21.3 \%$ dan yang memiliki perilaku tidak baik sebanyak 28.7\%. Dari data terlihat bahwa responden dengan persepsi kerentanan yang sedang cenderung memiliki perilaku yang tidak baik dalam pemenuhan kebutuhan nutrisi anaknya. Dalam jurnal penelitian (5) menemukan persepsi Ibu yang baik tentang kesehatan anak terutama status gizi anak hanya 49.5\% dan sebagian besar sebanyak 50.5\% mempunyai persepsi yang tidak baik.
Ibu yang dapat mempraktikkan perilaku pemberian makan seimbang pada anak hanya sekitar $62.5 \%$ (6). Hasil penelitian menunjukkan bahwa persepsi kerentanan tidak signifikan berhubungan dengan perilaku Ibu dalam pemenuhan kebutuhan nutrisi bagi anaknya ( $\mathrm{p}=0.382)$. Dari data diatas dapat dilihat bahwa walaupun tidak ada signifikan hubungan persepsi kerentanan dengan perilaku Ibu dalam pemenuhan kebutuhan nutrisi pada anaknya akan tetapi terlihat responden dengan persepsi kerentanan yang tinggi lebih banyak yang mempunyai perilaku yang baik dari pada perilaku yang tidak baik.

Masih adanya responden yang memiliki perilaku yang tidak baik dalam pemenuhan kebutuhan nutrisi anaknya kemungkinan dapat terjadi karena berhubungan dengan faktor demografi yaitu 
pendidikan responden yang masih rendah sebanyak $42 \%$ tamatan SD/sederajat, dimana $28.8 \%$ mempunyai perilaku yang tidak baik hanya $13.2 \%$ berperilaku baik. Pendapatan juga merupakan faktor demografi yang mempengaruhi perilaku responden. Dari $66.7 \%$ dengan pendapatan dibawah UMR ditemukan $37,4 \%$ berperilaku tidak baik dan hanya 29.3\% berperilaku baik. Hal ini sesuai dengan teori yang dikatakan oleh (7) bahwa kerentanan merupakan penilaian subjektif bagi setiap individu, ini dapat dipengaruhi oleh beberapa hal yaitu faktor umur, penghasilan, etnis, dan pengetahuan seseorang.

4.2 Hubungan antara persepsi keseriusan dengan perilaku Ibu dalam pemenuhan kebutuhan nutrisi bagi usia toddler

Data silang menunjukkkan bahwa responden dengan persepsi keseriusan yang rendah sebanyak 27\%, dimana 10,9\% memiliki perilaku yang baik dalam memenuhi kebutuhan nutrisi anaknya sedangkan 16,1\% memiliki perilaku yang tidak baik dalam pemenuhan kebutuhan nutrisi anaknya. Dari data dapat dilihat bahwa responden dengan persepsi kerentanan yang rendah cenderung memilki perilaku yang tidak baik. Kemudian untuk persepsi keseriusan yang tinggi sebanyak 29.3\%, responden yang memiliki perilaku baik sebanyak $15.5 \%$ dan responden dengan perilaku tidak baik sebanyak 13.8\%. Responden dengan persepsi keseriusan yang tinggi lebih banyak dari pada perilku yang tidak baik. Responden dengan pesepsi keseriusan yang sedang sebanyak 43.7\%, dimana sebanyak 23.6\% memiliki perilaku yang baik dan $20.1 \%$ memiliki perilaku yang tidak baik.

Persepsi keseriusan yang rendah dari responden karena menganggap bahwa kekurangan gizi pada anaknya tidak dapat menyebabkan gangguan kesehatan yang sangat mengkuatirkan apalagi dapat menyebabkan kematian. Hal ini terlihat dari rendahnya jawaban responden pada pernyataan no 2 dan 7. Persepsi keseriusan yang rendah pada Ibu dipengaruhi oleh faktor demografi yaitu pendidikan responden yang masih rendah sebanyak $42 \%$ tamatan SD/sederajat, dimana 28.8\% mempunyai perilaku yang tidak baik hanya $13.2 \%$ berperilaku baik. Pendapatan juga merupakan faktor demografi yang mempengaruhi perilaku responden. Dari $66.7 \%$ dengan pendapatan dibawah UMR ditemukan 37,4\% berperilaku tidak baik dan hanya $29.3 \%$ berperilaku baik. Hal lain yang mungkin menyebabkan persepsi keseriusan yang masih rendah adalah anak mereka belum pernah mengalami gangguan kesehatan karena kekurangan gizi dan juga karena belum pernah ada kasus kematian pada anak karena kekurangan gizi di wilayah sekitar mereka tinggal.

Hasil penelitian menunjukkan bahwa persepsi keseriusan tidak signifikan berhubungan dengan perilaku Ibu dalam pemenuhan kebutuhan nutrisi bagi anaknya ( $p=0.127)$. Artinya persepsi keseriusan yang tinggi tidak membuat perubahan perilaku yang baik pada Ibu dalam hal pemenuhan kebutuhan nutrisi demikian juga jika Ibu memiliki persepsi keseriusan yang rendah bukan berarti Ibu tidak melakukan pemenuhan kebutuhan nutrisi dengan baik bagi anaknya. Persepsi keseriusan juga dipengaruhi oleh persepsi yang lain. Semakin tinggi persepsi kerentanan, manfaat, isyarat untuk bertindak serta keyakinan diri Ibu maka semakin tinggi pula persepsi keseriusan yang dimilikinya. Semakin tinngi persepsi keseriusan maka responden akan memiliki persepsi hambatan yang rendah.

4.3 Hubungan antara persepsi manfaat dengan perilaku Ibu dalam pemenuhan kebutuhan nutrisi bagi usia toddler

Data tabulasi silang responden yang memiliki persepsi manfaat rendah sebanyak 3.4\%, dimana $1.7 \%$ dan perilaku tidak baik $1.7 \%$. Persepsi manfaat rendah artinya responden tidak merasa ada manfaat/sama sekali tidak ada manfaat dari perilaku pemenuhan kebutuhan nutrisi bagi anaknya. Responden dengan persepsi manfaat yang tinggi sebanyak $58.6 \%$ dengan perilaku baik sebanyak $30.4 \%$ dan perilaku tidak baik sebanyak $28.2 \%$. Responden yang memiliki persepsi manfaat yang sedang sebanyak $37.9 \%$ dimana $17.8 \%$ dan $20.1 \%$ perilaku tidak baik. Dari data dilihat bahwa responden dengan persepsi manfaat yang tinggi lebih banyak yang perilakunya baik dari pada responden dengan perilaku tidak baik.

Penerimaan susceptibility sesorang terhadap suatu kondisi yang dipercaya dapat menimbulkan keseriusan (perceived threat) adalah mendorong untuk menghasilkan suatu kekuatan yang mendukung kearah perubahan perilaku. Ini tergantung pada kepercayaan seseorang terhadap efektivitas dari berbagai upaya yang tersedia dalam mengurangi ancaman penyakit, atau keuntungankeuntungan yang dirasakan (perceived benefit) dalam mengambil upaya-upaya kesehatan tersebut (7) Sesuai teori diatas seharusnya responden yang memiliki persepsi manfaat yang tinggi akan memiliki perilaku pemenuhan kebutuhan yang baik.

Akan tetapi dari temuan peneliti pada responden yang memiliki persepsi manfaat yang tinggi masih ditemukan perilaku Ibu yang tidak baik dalam pemenuhan kebutuhan nutrisi pada anaknya. Hal ini kemungkinan disebabkan oleh faktor demografi responden yaitu tingkat pendidikan yang rendah dan pendapatan ekonomi yang masih rendah juga. Dari 42 $\%$ tamatan SD/sederajat, sebanyak $28.8 \%$ mempunyai perilaku yang tidak baik hanya $13.2 \%$ berperilaku baik. Pendapatan juga merupakan faktor demografi yang mempengaruhi perilaku responden. Dari $66.7 \%$ dengan pendapatan dibawah UMR ditemukan $37,4 \%$ berperilaku tidak baik dan hanya 29.3\% berperilaku baik. Hasil penelitian menunjukkan bahwa persepsi manfaat tidak signifikan berhubungan dengan perilaku Ibu dalam pemenuhan kebutuhan nutrisi bagi anaknya $(\mathrm{p}=$ 0.182). Artinya walaupun persepsi manfaat yang 
Tabel 3. Hubungan antara persepsi kerentanan, persepsi keseriusan, persepsi manfaat, persepsi hambatan, cues to action dan self eficacy dengan perilaku Ibu dalam pemenuhan kebutuhan nutrisi pada anak usia toddler di Puskesmas Kawangu, Desember 2018

\begin{tabular}{|c|c|c|c|c|c|c|c|}
\hline \multirow{3}{*}{ Variabel } & \multirow{3}{*}{ Hasil } & \multicolumn{4}{|c|}{$\begin{array}{l}\text { Perilaku Ibu dalam pemenuhan kebutuhan nutrisi } \\
\text { pada anaknya }\end{array}$} & \multirow{2}{*}{\multicolumn{2}{|c|}{ Total }} \\
\hline & & Perilaku & k baik & Perila & aik & & \\
\hline & & Frekuensi & $\%$ & Frekuensi & $\%$ & $\Sigma$ & $\%$ \\
\hline \multirow{5}{*}{$\begin{array}{l}\text { Persepsi } \\
\text { Kerentanan }\end{array}$} & Rendah & 17 & 9.8 & 21 & 12 & 38 & 21,8 \\
\hline & Sedang & 50 & 28.7 & 37 & 21.3 & 87 & 50 \\
\hline & Tinggi & 20 & 11.5 & 29 & 16.7 & 49 & 28,2 \\
\hline & Total & 87 & 50 & 87 & 50 & 174 & 100 \\
\hline & Spearmen & $\mathrm{p}=0.382, \mathrm{r}$ & & & & & \\
\hline \multirow{5}{*}{$\begin{array}{l}\text { Persepsi } \\
\text { Keseriusan }\end{array}$} & Rendah & 28 & 16.09 & 19 & 10.91 & 47 & 27,0 \\
\hline & Sedang & 35 & 20.13 & 41 & 23.57 & 76 & 43,7 \\
\hline & Tinggi & 24 & 13.78 & 27 & 15.52 & 51 & 29,3 \\
\hline & Total & 87 & 50 & 87 & 50 & 174 & 100,0 \\
\hline & Spearmen & $p=0.116, r$ & & & & & \\
\hline \multirow{5}{*}{$\begin{array}{l}\text { Persepsi } \\
\text { manfaat }\end{array}$} & Rendah & 3 & 1.7 & 3 & 1.7 & 6 & 3,4 \\
\hline & Sedang & 35 & 20.1 & 31 & 17.8 & 66 & 37,9 \\
\hline & Tinggi & 49 & 28.2 & 53 & 30.4 & 102 & 58,6 \\
\hline & Total & 87 & 50 & 87 & 50 & 174 & 100 \\
\hline & Spearmen & $\mathrm{p}=0.182, \mathrm{r}$ & & & & & \\
\hline \multirow{5}{*}{$\begin{array}{l}\text { Persepsi } \\
\text { hambatan }\end{array}$} & Rendah & 7 & 4 & 2 & 1.2 & 9 & 5,2 \\
\hline & Sedang & 33 & 19 & 32 & 18.4 & 65 & 37,4 \\
\hline & Tinggi & 47 & 27.0 & 53 & 30.5 & 100 & 57,5 \\
\hline & Total & 87 & 50 & 87 & 50 & 174 & 100 \\
\hline & Spearmen & $\mathrm{p}=0.033, \mathrm{r}=$ & & & & & \\
\hline \multirow{5}{*}{ Cues to action } & Rendah & 3 & 1.7 & 4 & 2.3 & 7 & 4 \\
\hline & Sedang & 42 & 24.2 & 34 & 19.5 & 76 & 43,7 \\
\hline & Tinggi & 42 & 24.1 & 49 & 28.2 & 91 & 52,3 \\
\hline & Total & 87 & 50 & 87 & 50 & 174 & 100 \\
\hline & Spearmen & $\mathrm{p}=0.075, \mathrm{r}=$ & & & & & \\
\hline \multirow{5}{*}{ Self eficacy } & Rendah & 4 & 2.3 & 4 & 2.3 & 8 & 4,6 \\
\hline & Sedang & 52 & 29.87 & 42 & 24.13 & 94 & 54 \\
\hline & Tinggi & 31 & 17,83 & 41 & 23.57 & 72 & 41,4 \\
\hline & Total & 87 & 50 & 87 & 50 & 174 & 100 \\
\hline & Spearmen & $\mathrm{p}=0.115, \mathrm{r}=$ & & & & & \\
\hline
\end{tabular}

dimiliki responden tinggi tetapi tidak mempengaruhi perilaku yang baik dalam pemenuhan kebutuhan nutrisi anaknya, sebaliknya jika persepsi manfaat responden rendah tidak otomatis responden akan mempunyai perilaku yang tidak baik dalam pemenuhan kebutuan nutrisi. Semakin tinggi persepsi kerentanan, persepsi keseriusan, persepsi manfaat, isyarat untuk bertindak serta keyakinan diri Ibu maka akan semakin tinggi manfaat yang dirasakan, sebaliknya persepsi yang dirasakan akan rendah.

4.4 Hubungan antara persepsi hambatan dengan perilaku Ibu dalam pemenuhan kebutuhan nutrisi bagi usia toddler

Data tabulasi silang menunjukkkan bahwa responden dengan persepsi hambatan yang tinggi sebanyak $5.2 \%$,dimana $1.2 \%$ responden memiliki perilaku yang baik dalam pemenuhan kebutuhan nutrisi sedangkan $4.0 \%$ responden memniliki perilaku tidak baik dalam pemenuhan kebutuhan nutrisi. Dapat dilihat bahwa responden dengan persepsi hambatan yang tinggi lebih banyak memiliki perilaku yang tidak baik.
Responden yang memiliki persepsi hambatan yang rendah sebanyak 57.5\%, dimana $30.5 \%$ memiliki perilaku yang baik sedangkan sebanyak 27.0\% memiliki perilaku yang tidak baik dalam pemenuhan kebutuhan nutrisi anaknya, terlihat bahwa responden dengan persepsi hambatan rendah cenderung mempunyai perilaku yang baik dari pada responden yang memiliki perilaku tidak baik. Responden yang memiliki persepsi hambatan sedang sebanyak $37.4 \%$ dimana $18.4 \%$ dengan perilaku baik dan 19\% dengan perilaku tidak baik. Responden dengan persepsi hambatan sedang lebih banyak yang memiliki perilaku tidak baik.

Perceived barriers merupakan segala sesuatu yang menghambat individu dalam melakukan perubahan perilaku tertentu (7). Dalam teori HBM dijelaskan bahwa segala sesuatu yang menghambat ini dapat dilihat dari segi biaya yang mahal, manfaat, pelayanan kesehatan yang tidak memuaskan dan menyenangkan serta dukungan dari keluarga dan lainnya. Sejalan dengan jurnal penelitian (8) hambatan yang dirasakan orangtua dalam menyediakan makanan yang sehat adalah biaya makanan yang mahal, jarak ketempat pembelian dan keterbatasan produk makanan yang segar. Hal ini 
juga terlihat dari data bahwa dari $66.7 \%$ dengan pendapatan dibawah UMR ditemukan 37,4\% berperilaku tidak baik dan hanya $29.3 \%$ berperilaku baik. Hasil penelitian menunjukkan bahwa persepsi hambatan signifikan berhubungan sangat lemah dengan perilaku Ibu dalam pemenuhan kebutuhan nutrisi bagi anaknya ( $\mathrm{p}=0.033$ ). Artinya bahwa semakin responden merasakan hambatan/rintangan dalam pemenuhan kebutuhan nutrisi maka akan diikuti oleh semakin tingginya perilaku yang tidak baik dalam hal pemenuhan kebutuhan nutrisi pada anaknya. Sebaliknya jika hambatan yang dirasakan rendah maka semakin tinggi pula perilaku Ibu yang baik dalam pemenuhan kebutuhan nutrisi anaknya. Persepsi hambatan juga dipengaruhi oleh persepsi yang lain. Semakin tingginya persepsi kerentanan, persepsi keseriusan, persepsi manfaat, isyarat untuk bertindak, keyakinan diri maka hambatan yang dirasakan akan rendah karena merasa lebih banyak manfaat yang dirasakan daripada kerugiannya.

4.5 Hubungan antara cues to action dengan perilaku Ibu dalam pemenuhan kebutuhan nutrisi bagi usia toddler

Data tabulasi silang menunjukkan bahwa responden dengan cues to action rendah sebanyak $4.0 \%$, dimana $2.3 \%$ memiliki perilaku yang baik dan $1.7 \%$ memiliki perilaku yang tidak baik. Responden dengan cues to action tinggi sebanyak 52.3\%, dimana $28.2 \%$ memiliki perilaku yang baik dan $24.1 \%$ memiliki perilaku yang tidak baik. Responden dengan cues to action tinggi lebih banyak yang mempunyai perilaku yang baik dari pada yang tidak baik.

Responden dengan Cues to action sedang sebanyak $43.7 \%$, dimana perilaku yang baik $19.5 \%$ dan perilaku yang tidak baik sebanyak $24.2 \%$. Dari data terlihat bahwa responden dengan perilaku sedang lebih banyak yang mempunyai perilaku yang tidak baik. Cues to action suatu perilaku dipengaruhi oleh suatu hal yang menjadi isyarat bagi seseorang untuk melakukan suatu tindakan atau perilaku (9)

Isyarat-isyarat yang berupa faktor-faktor eksternal maupun internal, misalnya pesan-pesan pada media massa, nasihat atau anjuran kawan atau anggota keluarga lain, aspek sosiodemografis misalnya tingkat pendidikan, lingkungan tempat tinggal, pengasuhan dan pengawasan orang tua, pergaulan dengan teman, agama, suku, keadaan ekonomi, sosial, dan budaya.

Hasil penelitian menunjukkan bahwa cues to action tidak signifikan berhubungan dengan perilaku Ibu dalam pemenuhan kebutuhan nutrisi bagi anaknya ( $p=0.075)$. Petunjuk untuk berperilaku cukup dan memiliki balita dengan status gizi baik serta ada hubungan antara petunjuk untuk berperilaku orang tua dengan status gizi balita. Dari data diatas dapat dilihat bahwa walaupun tidak ada signifikan hubungan isyarat untuk bertindak dengan perilaku Ibu dalam pemenuhan kebutuhan nutrisi pada anaknya akan tetapi terlihat responden dengan isyarat untuk bertindak yang tinggi lebih banyak yang mempunyai perilaku yang baik dari pada perilaku yang tidak baik. Masih adanya responden yang memiliki perilaku yang tidak baik dalam pemenuhan kebutuhan nutrisi anaknya kemungkinan disebabkan oleh faktor demografi responden dengan tingkat pendidikan yang rendah dan juga ekonomi/pendapatan responden yang rendah. Sebanyak $42 \%$ tamatan SD/sederajat dimana $28.8 \%$ mempunyai perilaku yang tidak baik hanya $13.2 \%$ berperilaku baik. Pendapatan juga merupakan faktor demografi yang mempengaruhi perilaku responden. Dari $66.7 \%$ dengan pendapatan dibawah UMR ditemukan $37,4 \%$ berperilaku tidak baik dan hanya $29.3 \%$ berperilaku baik.

Walaupun petugas kesehatan selalu memberikan penyuluhan tentang makanan dengan gizi seimbang tapi hal tersebut tidak membuat responden memiliki perilaku yang baik dalam pemenuhan kebutuhan nutrisi. Selain karena fakor demografi pendidikan dan pendapatan hal lain yang mungkin bisa menyebabkan perilaku Ibu dalam pemenuhan kebutuhan nutrisi belum baik karena mereka belum mengalami pengalaman yang menakutkan karena kekurangan gizi pada anaknya dan juga belum ada kasus kematian anak yang disebabkan karena kekurangan gizi. Isyarat untuk bertindak juga dipengaruhi oleh persepsi yang lain. Semakin tinggi persepsi kerentanan, persepsi keseriusan, persepsi manfaat keyakinan diri maka isyarat bertindak semakin tinggi sebaliknya persepsi hambatan akan rendah.

4.6 Hubungan antara self eficacy dengan perilaku Ibu dalam pemenuhan kebutuhan nutrisi bagi usia toddler

Tabulasi data silang diatas responden dengan dengan self eficacy yang rendah sebanyak $4.6 \%$ dengan perilaku baik sebanyak $2.3 \%$ dan perilaku tidak baik sebanyak 2.3\%. Responden dengan self eficacy yang tinggi sebanyak $41.4 \%$ dengan perilaku yang baik $23,57 \%$ dan responden dengan perilaku yang tidak baik 17.83\%. dengan self eficacy yang tinggi lebih banyak yang mempunyai perilaku yang baik dari pada yang tidak baik. Responden dengan self eficacy sedang sebanyak $54.0 \%$ dimana perilaku baik sebanyak $24.13 \%$ dan perilaku tidak baik sebanyak $29.87 \%$.

Responden dengan self eficacy sedang lebih banyak yang memiliki perilaku yang tidak baik dalam hal pemenuhan kebutuhan nutrisi pada anaknya. Self eficacy yang rendah artinya keyakinan/kepercayaan diri rendah dari responden sebaliknya Self eficacy yang tinggi artinya keyakinan/kepercayaan diri responden tinggi.

Menurut Teori Kognitif Sosial (10), rasa kontrol pribadi memfasilitasi perubahan perilaku kesehatan. Dari teori diatas dapat disimpulkan bahwa semakin tinggi self eficacy seseorang maka semakin baik perilaku kesehatan yang ditunjukkan, sebaliknya semakin rendah self eficacy seseorang maka perubahan perilaku kesehatan tidak baik atau kurang baik. 
Hasil temuan peneliti, responden dengan self eficacy tinggi tidak semuanya memiliki perilaku pemenuhan kebutuhan nutrsi yang baik, dan sebaliknya responden dengan self eficacy rendah tidak semuanya memiliki perilaku pemenuhan kebutuhan nutrsi yang tidak baik. Hal ini kemungkinan disebabkan karena tidak ada nya kepercayaan diri terhadap kemampuan Ibu dalam menyusun, meyediakan, dan mengolah makanan yang memenuhi unsur gizi sesuai dengan kebutuhan anak, terlihat dari jawaban responden memperoleh nilai yang rendah pada pernyataan no 1, 2 dan 4 . Tingkat pendidikan yang rendah sehingga tidak mempunyai cukup pengetahuan tentang bagaimana memilih, mengolah, menyusun menu dengan gizi seimbang bagi anaknya dan juga karena faktor ekonomi yang rendah sehingga tidak memiliki kemampuan untuk meyediakan bahan makanan dengan gizi seimbang.

Hasil penelitian menunjukkan bahwa self eficacy tidak signifikan berhubungan dengan perilaku Ibu dalam pemenuhan kebutuhan nutrisi bagi anaknya $(\mathrm{p}$ $=0.132$ ). Artinya self eficacy responden tidak mempengaruhi perilakunya dalam memenuhi kebutuhan nutrisi bagi anaknya. Self eficacy juga dipengaruhi oleh persepsi yang lain. Semakin tinggi persepsi kerentanan, persepsi keseriusan, persepsi manfaat, cues to action maka semakin tinggi pula self eficacy responden. Semakin rendah persepsi hambatan maka akan semakin tinggi self eficacy responden.

\section{KESIMPULAN}

Persepsi kerentanan tidak mempengaruhi perilaku Ibu dalam pemenuhan kebutuhan nutrisi pada anaknya.Persepsi keseriusan tidak mempengaruhi perilaku Ibu dalam pemenuhan kebutuhan nutrisi pada anaknya. Ibu tidak merasa bahwa kekurangan gizi pada anaknya dapat menyebab gangguan kesehatan yang serius apalagi sampai meninggal. Banyak atau sedikit nya manfaat yang dirasakan tidak mempengaruhi perilaku Ibu dalam pemenuhan kebutuhan nutrisi bagi anaknya. Semakin tinggi hambatan yang dirasakan maka semakin tidak baik perilaku Ibu dalam pemenuhan kebutuhan nutrisi, sebaliknya jika persepsi hambatan rendah maka perilaku Ibu akan baik. Tinggi rendahnya faktor cues to action tidak mempengaruhi perilaku Ibu dalam memenuhi kebutuhan anaknya. Keyakinan / kemampuan diri dari seorang Ibu tidak mempengaruhi perilaku Ibu dalam memenuhi kebutuhan nutrisi pada anaknya. Banyak responden yang merasa tidak mampu untuk menyediakan bahan makanan dan mengolah bahan makan dengan baik.

Bagi Puskesmas agar lebih memberikan edukasi terutama tentang makanan yang bergizi, Zat gizi makro dan mikro yang terkandung dalam makan, cara pengolahan yang baik dan benar serta bahaya apa yang mungkin bisa timbul bila anak kekurangan gizi terutama pada periode emas (usia toddler).Untuk responden agar lebih memberdayakan makanan lokal yang tersedia menjadi sumber gizi pengganti serta memanfaatkan pekarangan rumah agar dijadikan kebun keluarga dengan menanam berbagai jenis macam sayur-sayuran.sedangkan bagi peneliti selanjutnya dapat meelakukan penelitian dengan memberikan intervensi secara audio visual untuk meningkatkan perilaku Ibu dalam pemenuhan kebutuhan nutrisi bagi anaknya.

\section{UCAPAN TERIMA KASIH}

Kami mengucapkan terima kasih kepada Kepala Dinas Kesehatan Kabupaten Sumba timur, Kepala Puskesmas Kawangu untuk ijin dan penerimaan kami untuk mengambil data sebagai bahan penelitian dan semua Ibu di wilayah kerja yang bersedia menjadi responden.

\section{DAFTAR PUSTAKA}

1. World Health Organization. Infant mortality. 2010.

2. Nancy, Arifin. Gizi Buruk, Ancaman Generasi yang Hilang. Artik Inov Ed Vol 5/XVII/November 2005. 2005;

3. Dinas Kesehatan Kabupaten Sumba Timur. Profil Kesehatan Sumba Timur 2017. 2017.

4. Puskesmas Kawangu. Data Puskesmas Kawangu. 2017.

5. Langi G, Hongkrailert N, Sillabutra J. Knowledge and Perception of Mothers About Nutritional Status of Children Under Five Years of Age in Bahu Health Center, Manado City, North Sulawesi Province, Indonesia. Jurnal of Public Health and Dev. J public Heal Dev. 2008;

6. Virani. Hubungan Antara Pengetahuan dan Kebiasaan Konsumsi Fast Food Dengan Kejadian Gizi Lebih Pada Siswa Sekolah Dasar Negeri Sudirman I Makasar. Skripsi, Progr Stud Ilmu Gizi Fak Kesehat Masyarakat, Univ Hasanudin, Skripsi tidak dipublikasikan. 2011;

7. Glanz K, Rimer BK, Viswanath $\mathrm{K}$ (Kasisomayajula). Health behavior: theory, research, and practice. In: Health behavior and health education. 2015.

8. Granderson I, McDonald A. Parents' perceptions of healthy eating practices in north-east Trinidad. Proc Singapore Healthc. 2018;

9. Corner,Mark,Norman P. Predicting Health Behavior. Buckingham Open University; 2005.

10. Bandura A, Freeman W, Lightsey R. Self Eficacy: The Exercise of Control. New York: Freeman; 1999. 